\title{
Historical Development and Transformation of Vali-Asr Street, Tehran
}

\author{
Aynaz Lotfata ${ }^{1}$, Musa Panahandehkhah ${ }^{2} \&$ Yasin Lotfata $^{3}$ \\ ${ }^{1}$ Mississippi State University, Ankara, Turkey \\ ${ }^{2}$ University of Tehran, Tehran, Iran \\ ${ }^{3}$ Middle East Technical University, Ankara, Turkey \\ Correspondence: Aynaz Lotfata, Mississippi State University, Ankara, Turkey. E-mail: a.lotfata@gmail.com
}

Received: August 31, 2018

Accepted: September 22, $2018 \quad$ Online Published: September 28, 2018

doi:10.5539/jsd.v11n5p249

URL: https://doi.org/10.5539/jsd.v11n5p249

\begin{abstract}
Urban spaces throughout history have played a significant role in the socio-economic life of the inhabitants and have served as the center for communication and transformation in the cities. Study of historical periods and the development of urban space lead to our understanding of human perception toward life in different periods. The historically confluence of sociopolitical and economic changes shapes urban setting. The historical development of Vali Asr Street investigated to examine sociopolitical dynamics in development and transformation of urban space in the center of Tehran metropolitan. This paper contributes in identification of opportunities, threats, weaknesses and strengths in the three approaches for Vali-Asr street that might be used as assessment indicators for future development of urban space.
\end{abstract}

Keywords: historical development, sociopolitical dynamics, urban space, vali-asr street, Tehran

\section{Introduction}

Any physical space created to engage users in a particular activity and to meet the needs and desires of individuals. Economic, social and political developments in the twentieth century have been the most influential factors in the extent and development of Iran's urban space. The upheavals in society and shifts in socioeconomic system result in the structural change. The political divisions, land reforms and economic development contribute these changes (Lotfata, 2008). From dependency to agriculture and livestock productions to the oil-centered economic development in 1907 caused the sociospatial change. Oil incomes contributed the physical growth, development and urban spatial transformation (Pilehvar, 2007). Streets as an indication of modernism in 1933 transformed Tehran urban structure (Habibi, 1996). Indeed, the socialismcapitalism system of the Pahlavi government aimed to transform Iran's society. Conducting land reforms in 1962 and connecting to global network attempted to drive Iran's society towards a consumption society (Lotfata, 2015). In 1962-66, government considered the rational comprehensive plans and paid attention to urbanization as a significant issue (Pilehvar, 2007). Urban development plans in Iran are based on a comprehensive planning system where attention is paid to programs of land usage. Nation-state acts as the core unit of socio-economic space (Azad Aramaleki, 1991 and Lotfata, 2013). After the Islamic Republic of Iran, Islamic approach reconstructed the urban setting. Rapid population growth transformed Iran's urban centers.

The Vali-Asr Street like many other Iran urban space, is influenced by hasty actions of industrial development and modernism. The study area is the most visited historical urban center in the city center of Tehran Metropolitan and it considered among the social and political centers of the city. It presents major trends in the development of inner city space. The purpose of this research was to historically investigate the effect of sociopolitical and economic changes on the spatial structure of Vali-Asr Street. The method used in this paper is descriptive-analytic. Also, data collection method is library research and documents. This paper describes the evolution of historical structure of the street with reference to three periods of time 1- The First Pahlavi, 2- The Second Pahlavi, and 3- The Post-Islamic Revolution.

\section{Physical and Spatial Changes of Vali-Asr Street}

\subsection{The Core of the Street}

1920 's and late 1940's the government attempts to expand political and social institutions as well as economic institutions as means of securing long term political and economic intentions in order to prepare the ground for 
the transformation of the social structure (Rahnamaee and Shahhosseini,2005; Lotfata, 2018).

Vali-Asr Street is as an object of representation shifted the Islamic understanding of space as the subject of attention to a void where the ideas of openness of space and modern spaces were introduced. Street as a new urban symbol was added to the urban vocabulary of Tehran in this era. The street is no longer a track for cattle, but a machine for traffic, an apparatus for its circulation (Figure 1).

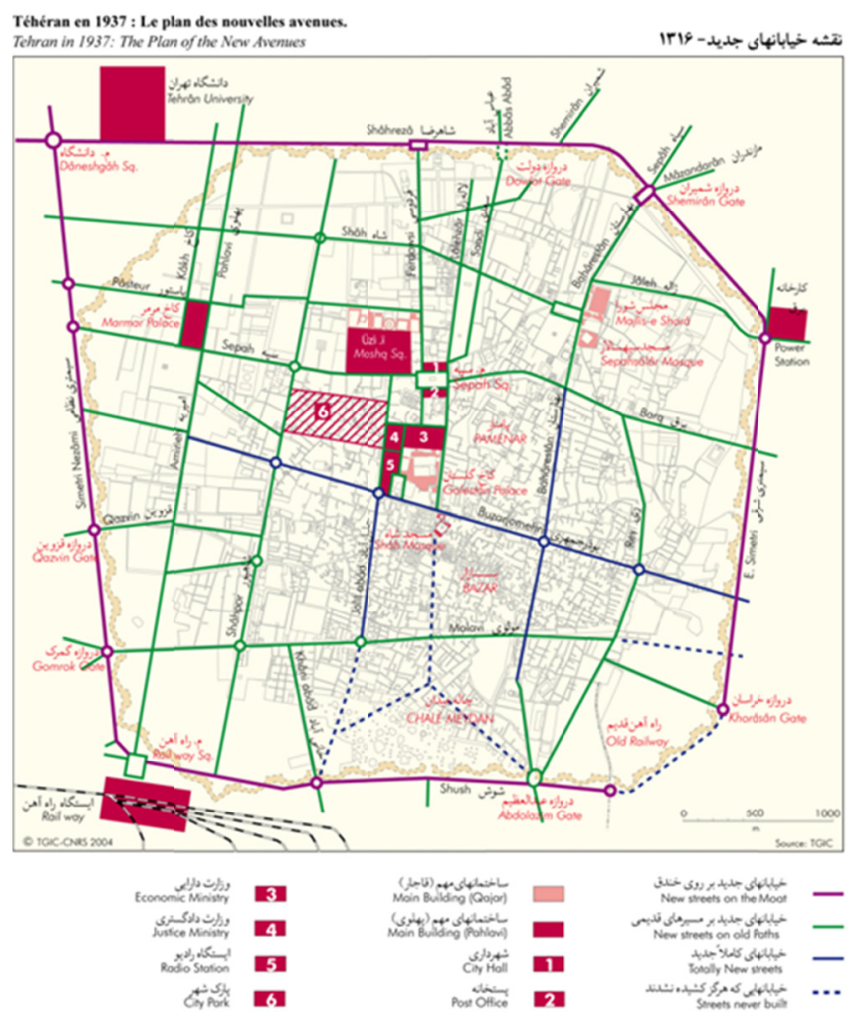

Figure 1. Tehran Street networks in the first Pahlavi era (1937)

(Source: http://www.irancarto.cnrs.fr/contents.php?v=3\&c=*\&l=en)

Reza shah determined modernizing vision as well as nationalistic intentions and dislike in religious intervention and breaking from Islamic conventions had empowered his modernizing efforts. Indeed, unlike Ataturk in Turkey, Reza shah managed to set a monarchy and considered a new constitution in revitalizing consciousness of the ancient Achaemenid architecture in terms of symbolism. Reza shah's efforts as Iran is no longer to be seen as a back warded country and Tehran as a representative city to itself and to the world must have embodied his principles in its social and urban landscape (Lenczowski, 1978).

The centralized Pahlavi government presents its power by building of monuments, modern squares and large avenues. Those were supposed to inspire openness, honesty and democracy in their appearance and be reflective of the new state by their own physical character. The undermining traditional elements introduces a new relationship between state and people (Grigor, 2009; Ambinakudige et al., 2017).

Today Vali-Asr Street is built by Reza Shah and named after the monarch the Pahlavi street traverse all the way from Tajrish square district in the north to the railway station in the south. The $18 \mathrm{~km}$ long street portrayed the state authority though a figurative representation. The Asphalt paved street featured tree-lined pedestrian paths with water from open irrigation ditches along its entire length. In the northern part it became the most fashionable and prestigious residential areas, housing villas and walk-up apartments. At major intersections commercial nodes, luxury shops and cafes appeared. The building regulation along the Pahlavi Street allowed only 2-story buildings-inspected by shah Him. The planning outlook of Shah was more of function, although aesthetics had been taken into account by planting plane trees alongside the route, formerly the Safavid favorite tree, later known as Chenarabbasi. The street transformed into a commercial hub attracting population and visitors.

In first Pahlavi era, Tehran start to experience outward development rather as previous years inward development 
of Tehran city. The outward growth of urban structure has been acquired through the imposition of the transportation networks and replacement of the old city walls with newly constructed streets and boulevards that prompted the penetration of urban functions and operations into different directions diverging from the central core of the city (Figure 2).

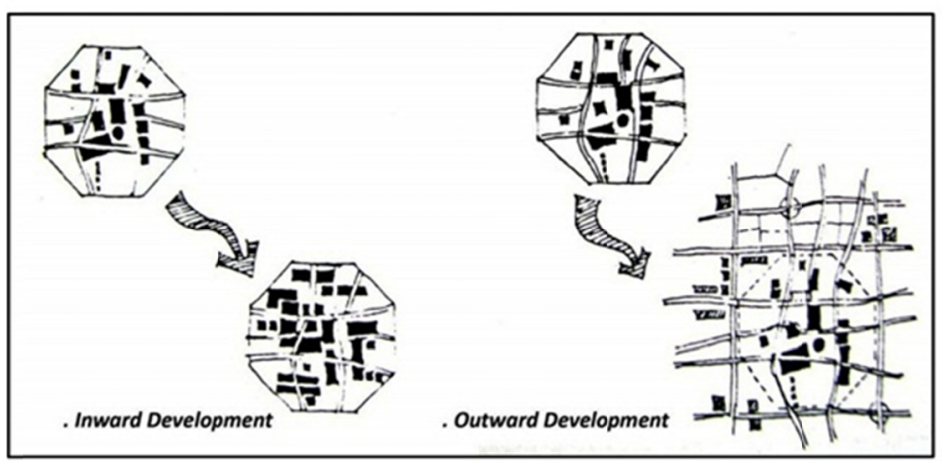

Figure 2. Inward and Outward development of Tehran city in the first Pahlavi era (Hamidi, 1997).

By the end of first Pahlavi era, the city grows almost 2.5 times bigger in scale than Qajar period. The first Pahlavi era with emerging the street network phenomenon restricts certain activities in city (Lotfata and Lotfata, 2018). According to renewal projects in first Pahlavi era which are residing within the core of the old city and old buildings such as the Arg complex that had been partially demolished and replaced by new governmental institutions. Indeed, with the change in the socio-political and economical system, industrial development was also added to the city purposes and caused changes in the structural properties of the city. Street grids contribute to transparency of urban spaces (Figure 3).

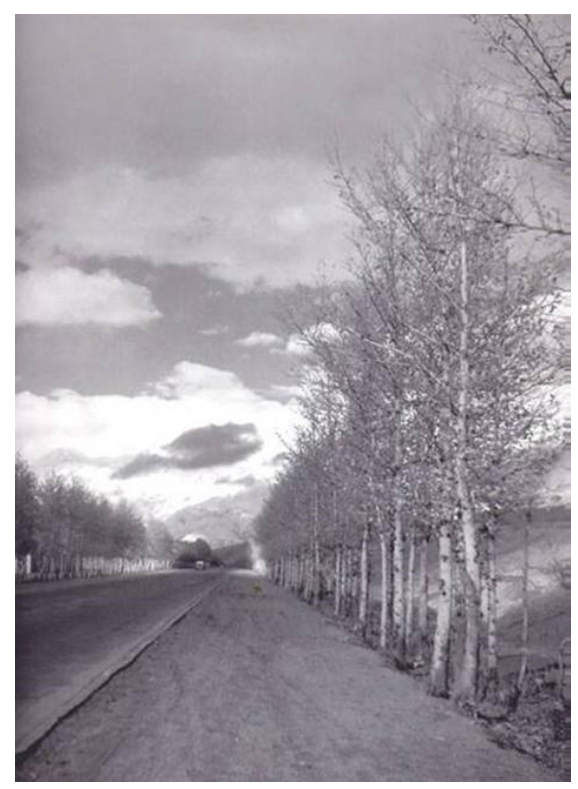

Figure 3. The Pahlavi Street in the first Pahlavi period (1955)

(Source: http://www.kavehfarrokh.com/iranica/pictures-of-iran/a-video-of-tehran-in-1957)

\subsection{Vali-Asr Street in the Second Pahlavi Period}

In the second Pahlavi era 'Reign of Mohammad Reza Shah', with white revolution, Shah aims to westernizing Tehran city from not only dismantling physical principles of modernization but also culturally, politically and economically changes of Tehran city. The second Pahlavi era has re-named era of land reform and privatization of government. Parallel to market-led modernization of 1963 in Tehran city, theories of equity and humanity also pose among Mohammad Reza Shah white revolution (Figure 4). 


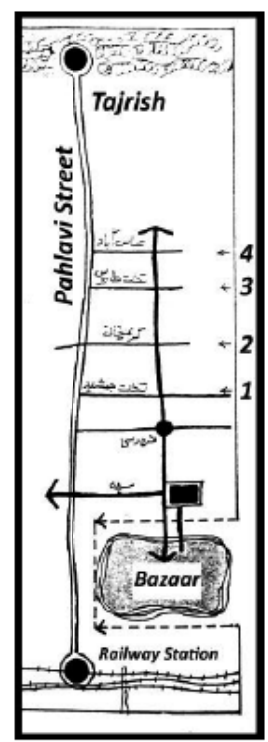

Figure 4. The development of commercial activities in the second Pahlavi era (Hamidi, 1997)

In the second Pahlavi era both physical and socio-cultural dimensions have been considered for reshaping the city. In this era the most important planning and design thought for transforming Tehran city to modernization path was master plan of 1970 that known as 'Groen-Farmanfarmaeian' plan. In that period of time, while the city tried to pretend as a modern capital of Iran, it went through some social, economic and demographic problems cause of white revolution; opposite religion groups, opposite feudal groups for lost their benefits and intensive immigration to Tehran in searching for work and better life. In that time the main part of urban population had been resided in central and south part of the city and north of the city was for recreational uses of Shah and royal families and it surrounded by villages such as Darake, Darband and Darabad (Figure 5).

Pahlavi (Today Vali-Asr) street connected Rey and Bazar in south, Abbas Abad in center and Shemiranat district in north and was the one of the two main street of Tehran (Figure 6). Additionally, since the first Pahlavi period the Vali-Asr Street contributed to re-spatialize the traditional street networks through the linkage south of the city to the north. This has followed in the modernization tries of the Tehran city (Figure 7).

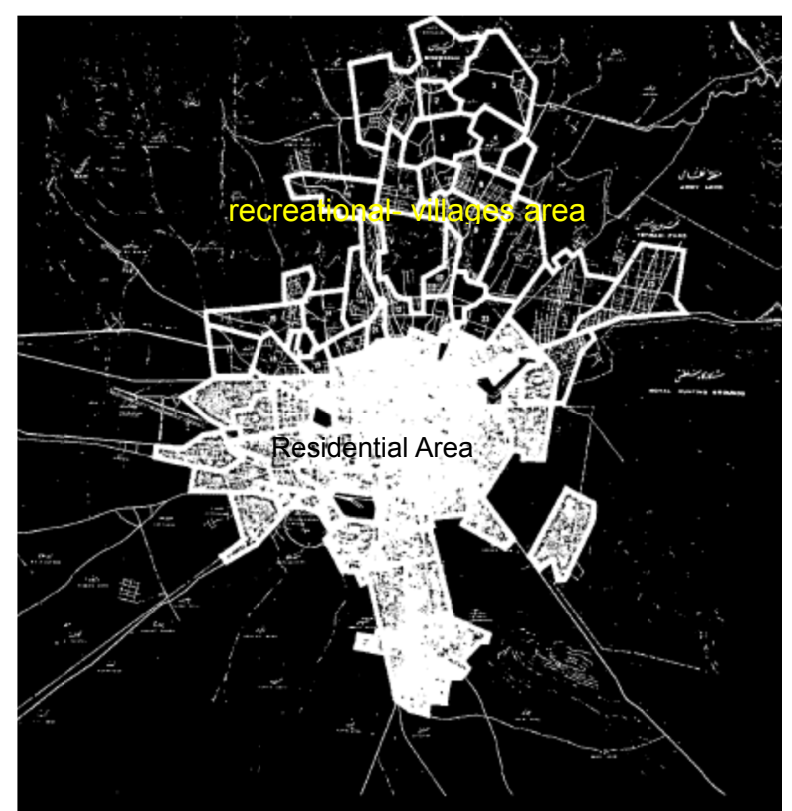

Figure 5. Residential and Recreational Villages of Tehran City 1970

(Source: Tehran master plan, 1970)

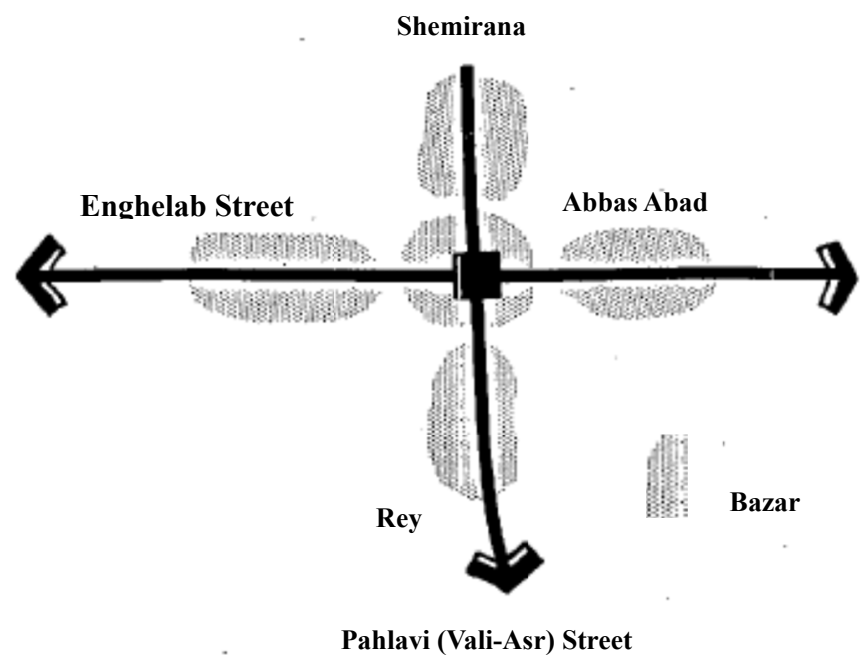

Figure 6. Tehran Structure in 1970

(Source: Tehran master plan, 1970) 


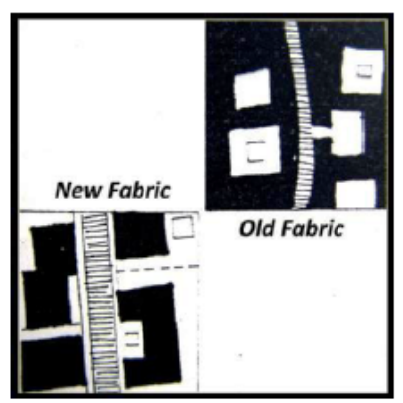

Figure 7. New form of open public space vs. Traditional open public space (Hamidi, 1997)

Pahlavi (Vali-Asr) Street was divided into two parts, the first part began from Rey and ended in central Tehran and the second part began from Abbas Abad up to Shemranat. Pahlavi was the name of North Street and the South name was 'Aramgah' road. In the master plan of 1970, it was proposed that these two streets should connect with each other in order to connect Rey (Religion and Bazar area) to central Tehran (CBD and Abbas Abad cores) and Shemiranat (Entertainment area). These two areas were completely different and had paradoxical personalities: while poor people and low classes lived in shape of shanty towns concentrated around Rey and central Tehran in the south street, high classes with luxury houses and big shops located near the north street. In central Tehran population density was high and it reduced as went to Shemiranat District. So, in the south part of the street was a hidden driving force for socio-economic unrest that Bazar elites supported that while in the north one situation was completely different: Pahlavi street was going to be the first-class street that had the assignment to showing the latest fashion and luxury modes of lifestyle. The street connected the variety of socio-economic classes although that did not prevent socio-spatial polarization and segregation. Besides, in that time Bazar was a great socio-economic force that had been affected by religion and radical clergymen and the street proximity to poor residents' region was a suitable opportunity to give the considerable pressures on government. Furthermore, middle classes were unsatisfied from their situation, because in the one hand they expected a life like high class groups of society and on the other hand Tehran city was in trouble with lack of houses, educational and welfare systems' facilities. Therefore, inhabitants could not easily achieve their socio-economic goals.

The main concept of 1970's plan was the liner development toward the west side of the city (Figure 8). The plan predicted in the next 25 years, urban population will increase with 80 percent and car ownership will raise up to 65 percent. Two of the most important aims of the plan were to reduce imbalances between different socio-economic groups of people through improving their accessibility to urban cores by long and major roads and quick transportation system (1970s master plan) (Figure 9).

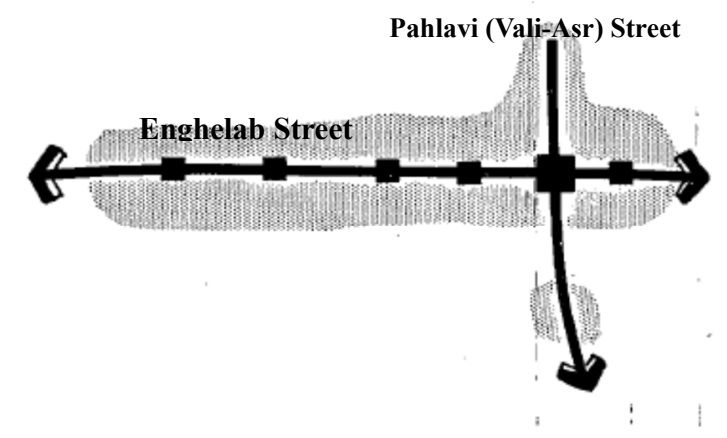

Figure 8. Overall Tehran development pattern in 1970's plan 


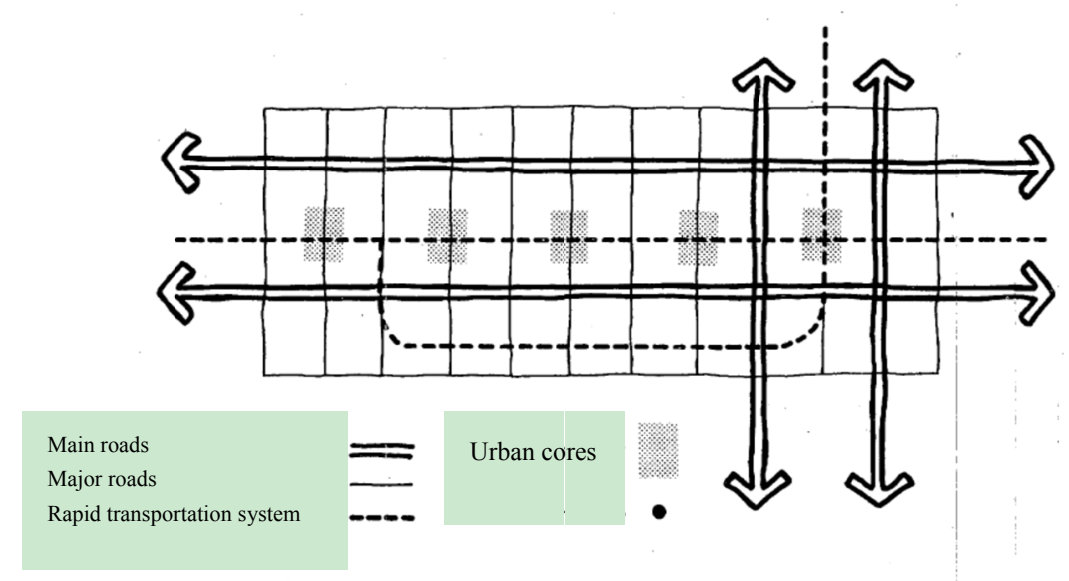

Figure 9. Selected urban cores distribution pattern and its accessibility network in 1970's plan

Besides of up-down modernization thought, it can be inferred that the ideological goal of liner development pattern was controlling Bazar driving force by making street accessible for military guards in case of riots, although that kind of planning and design strategy made urban spaces more sociable, because of that shopping and recreational activities.

It seems that Pahlavi street improve spatial justice by making bond among the great communities as Tehran Pars, Kan and Latmar and make urban facilities and services more accessible to people who lived throughout the city (Figure 10) while there were variety of unsatisfied classes, especially middle-class groups, that the city could not prepare enough and fair opportunities for them in order to access good jobs, suitable houses and so on. Additionally, there was not a radical thought for renovation and rehabilitation of shanty towns and old fabric in the plan (1970's master plan). So, in one hand a traditional and strong Bazar and in the other hand existence of both low and middle unsatisfied classes specially in south (Rey) and heart of the city (central Tehran) contributed the socio-politically unrest situation for Pahlavi (Vali-Asr) street.

The street has identified and territorized with the protestors' manifestations. The street protest has gone to be more worse through a strong connectivity of the Pahlavi street with that Pahlavi street had a strong connectivity with Enghelab Street as the second large street at Tehran city structure. That connectivity is a great potential for any street movements and the point where they get each other, there is a most powerful node for announcing anything. 


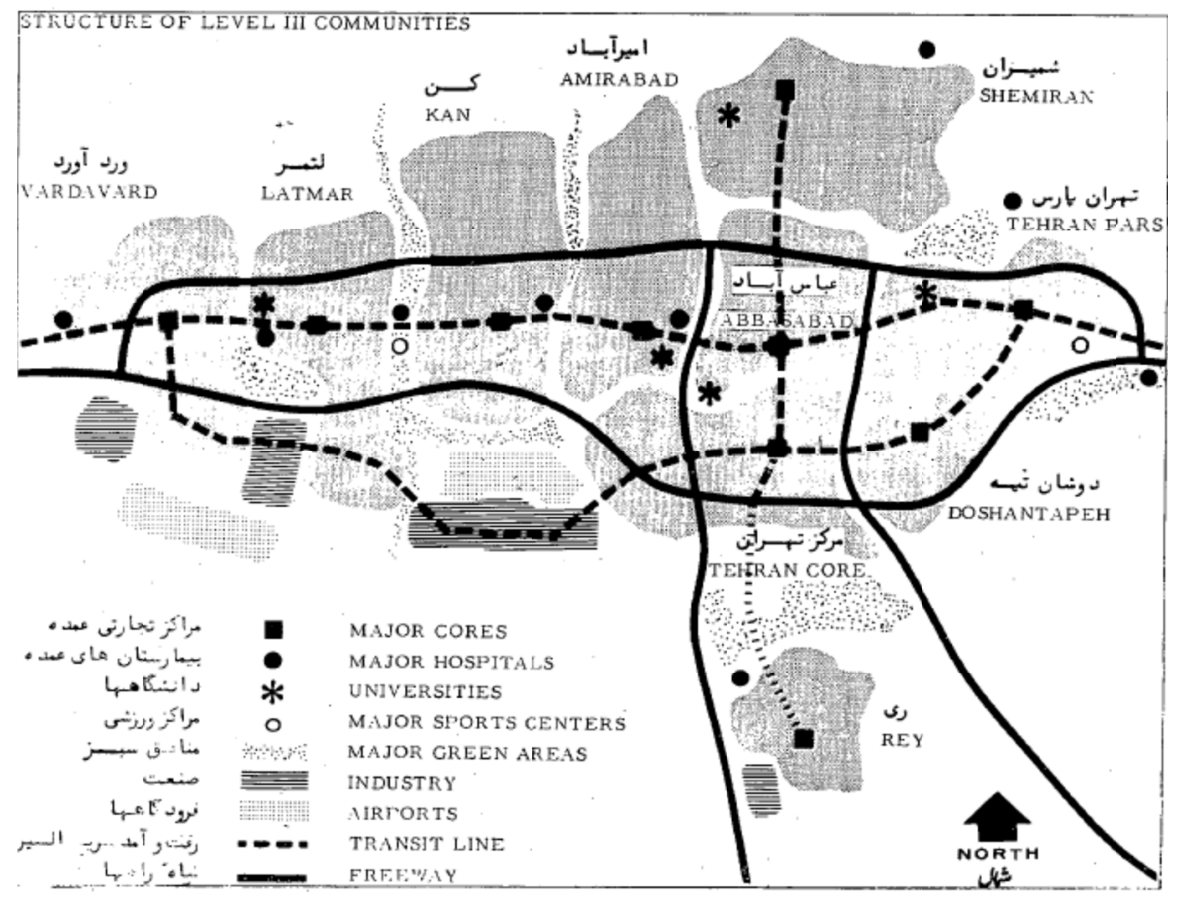

Figure 10. Spatial strategy of 1970's master plan

In summary, Pahlavi (Vali-Asr) street in the pre-revolution was a tool for two main goals: first, to make inhabitants mobility faster and easier than past. This goal was going to be more important when automobile came to Iran and attached to the city life especially in second Pahlavi period. Second, to improve spatial justice through connect residential and urban main services with each other from historical, religion and retail centers in south, administrative centers in central Tehran and entertainment and recreational in north. So, there were not the social dimension approach about Vali-Asr street in the plan. One reason that can find is an ideological one which has been seen street as a governmental ownership and some kind of ideology that citizens should only use facilities for daily coming and going activities (Figure 11). 


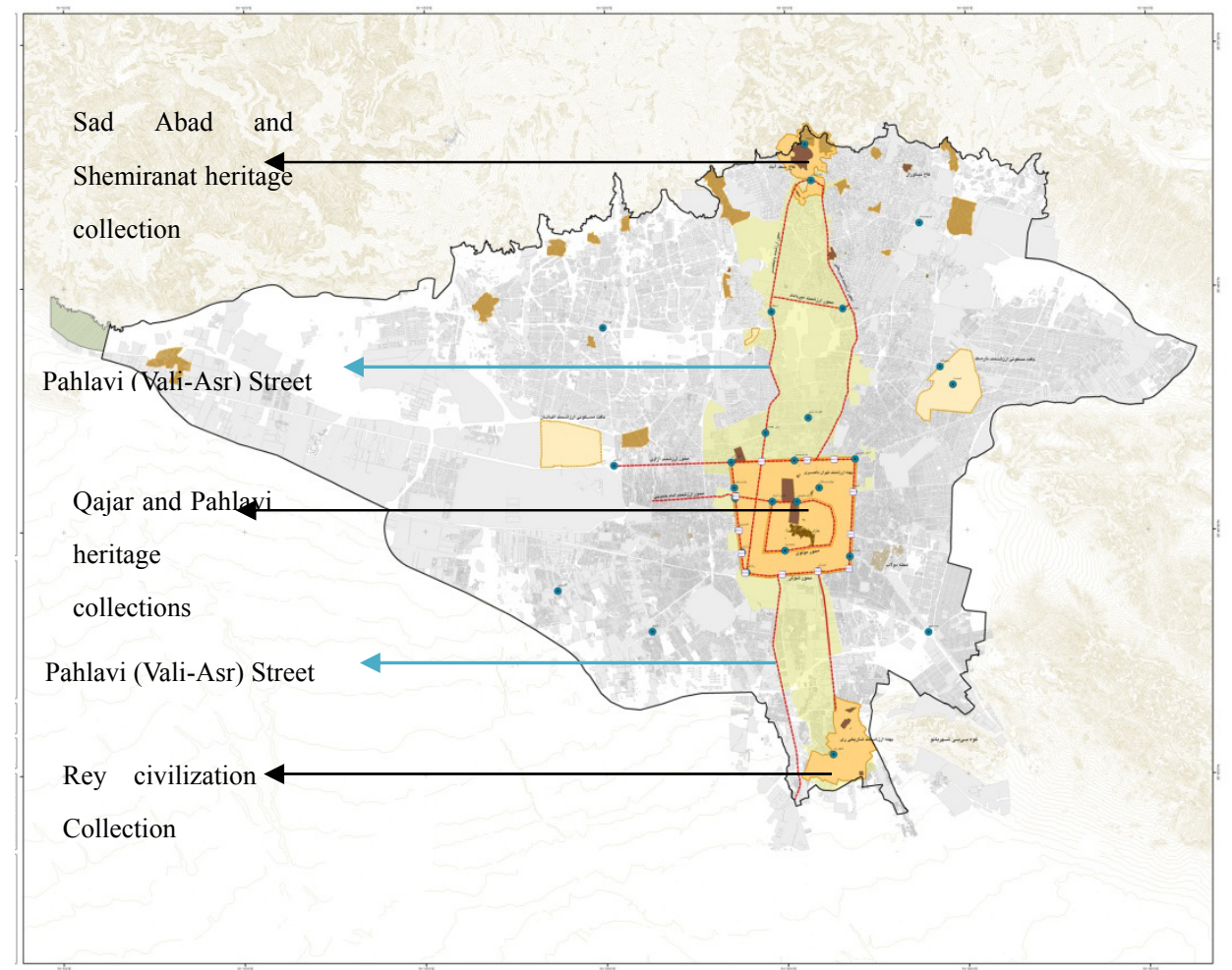

Figure 11. The cultural heritage places location in Tehran

\subsection{Vali-Asr Street in Post Revolution Period}

1979's revolution in Iran caused a great transformation in ideological system that affected whole thoughts and practices in country management and planning system. Tehran city in this period of time was center of whole political and social events. Royal system of country administration changed to republic-religion one and transformed from modernization path to radical revolutionary thoughts. In addition to revolution problems, Iran had involved a long-time war for eight years. And during revolution and war period (1979-1989), 1970's master plan had been stopped because of the ideological conflict and there were not plan or planning instead till 1991. In this year 'Atek' engineers consultants got the assignment to prepare a re-ordering plan for upset situation of the city. Between 1979 till 1991 Tehran managed by temporary instructions and brought it to the unplanned path. Street like other urban space suffered from the erratic growth that became uncontrollable after a while.

Restructuring of Tehran plan in 1991: Modified Tehran plan prepared for correcting the unequal and unstable growth of the city in between 1987 to 1991. After a period of war destruction, it was time of infrastructure improvements and fixing wrong decisions especially in Tehran city. Pahlavi Street that had been changed to Vali-Asr Street after revolution, like the other main street (Enghelab Street). Engelab Street was a location for showing ideological expositions. Government orders for managing urban spaces by religion signs such as change of bar land uses and former ideological signs in Vali-Asr Street. Practically speaking, up-down modernization method transformed to a traditional and religious method that wanted to use a maximum capacity of urban spaces, specially streets to show the governmental socio-political power.

In the modified plan of 1991, the main concept divided the city into 5 urban cores with independent nodes (re-ordering plan, 1991). Liner development of the city changed to the polycentric one, and Vali-Asr Street's role was a crucial in this plan, it connected south domain to north domain (Figure 12). In this plan there was a strong emphasis on subway for three main reasons: High trip production rate in the city especially to the CBD, high population density in CBD and law car ownership rate. They made a rapid and public transportation essential. It was proposed that 5 urban cores could connect with each other by subway and street combination networks. 


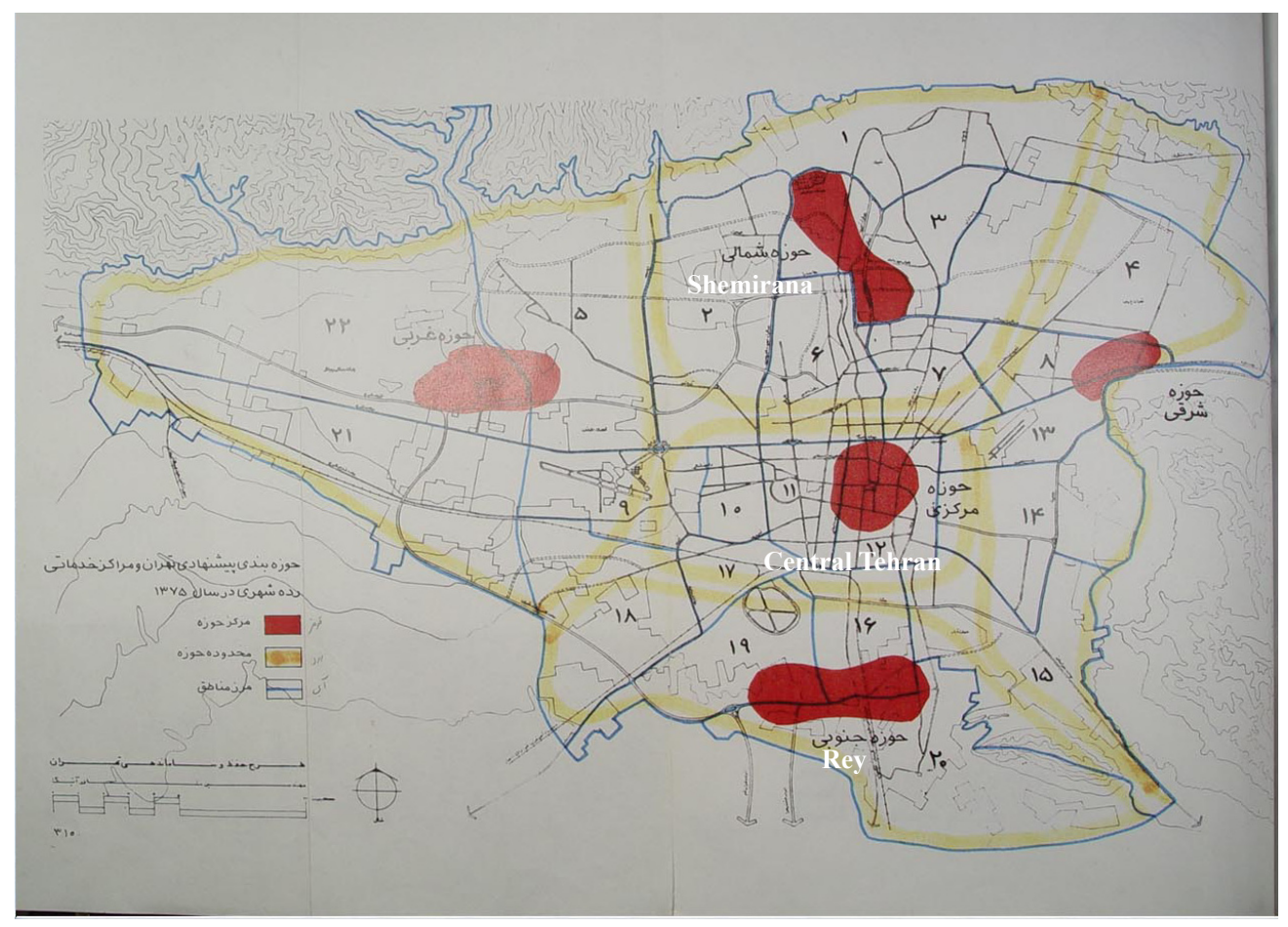

Figure 12. Overall development pattern of 1991's plan

With more investigating in the plan's proposals, it is becoming clear that there was not any sign of planning and design strategy for socio-economic role of street generally and Vali-Asr street in particular. There were not preparing strategies to enhance the quality of the street spaces for the presence of people in urban spaces. The only thought was how we could transport people faster and easier between urban cores in the first and second plan. In lack of attention to sociability of streets, the social unsuitability has become clear while Vali-Asr street brought historical, social and economic values for inhabitants in its long from south with Rey as an ancient region to central Tehran as a collection of architectural and art heritages up to Shemiranat as a recreational and royal center. Although it has unique position in Tehran structure as the main street, two past plans forgot this potential of it not only as a longest street in middle east but also as cultural heritage in Tehran and even in Iran. It must mention that re-ordering plan was a rapid and shallow response to the Tehran's problems after war and it could not has a comprehensive thought for urban spaces and their socio-economic qualities. Additionally, another plan titled "Tehran strategic 2001 plan" was prepared by Tehran municipality for response those kinds of problems, but it justly contained an implementation procedure which aims to solve executive difficulties.

Structural-Strategic plan of Tehran in 2005: In the first of 21 century Tehran became a regional metropolitan with about 7 million people and the most powerful and wealth capital of Iran. It faced with some serious problems simultaneously: lack of affordable housing, pollution and lack of quality in urban spaces because of inappropriate and un-sustainable development. The 1970 plan had been stopped for ideological transformation, 1991 plan could not manage the city and in addition to former problems, huge newcomers seeking for new jobs and suitable houses and of course new cultural and social position in the post-war weaken the socioeconomic context. In this atmosphere, in 2005 ministry of housing urban development with cooperation of Tehran municipality prepared the third master plan of Tehran with strategic approach. During preparing the plan, there was a useful paradigm shift in master plans through preparing plans with respecting on history of Tehran city. Planners and designers gave more attentions to urban spaces and their qualities. They paid more attention to the socio-economic potential of streets but as we see ahead there are not yet a comprehensive plan for the sociocultural scheme in the case of urban spaces (Lotfata, 2012).

The main concept of this plan was network and polycentric pattern with designing a structure in coordination between cultural and natural heritages of the city (Figure 13). The main cultural and historical heritage located in the Vali-Asr street path according to 2005 master plan. However, in this plan also, there was not any sign of emphasizing on social aspects of urban life in Tehran city. The only differences were historical and cultural view in 
the plan for conservation them through bringing them to the urban life as urban spaces and historical places. Indeed, establishment of main urban centers and historical sites from south to north of Vali-Asr street path is not planning and designing the street as cultural and historical urban space. Also, 2005 plan proposed an adjustment pattern for transforming a radial system to polycentric one, without paying attention to Vali-Asr Street as a tool for social enchantment and enhancing the presence of inhabitants in urban spaces.

It has been due to this kind of thought that streets' design is in government's domain and just government could decide about their roles and qualities. Recently happening proved this claim: cause of some traffic problems Vali-Asr street transformed from two-way transport way to one-way transport way. What is clear it is not aims to enhance social and spatial engagement of inhabitants: the aim was responding transport needs and it meant that increasing control on urban spaces. It seems that traffic problems and their solutions affected all socio-spatial issues in Tehran specially the Vali-Asr street.
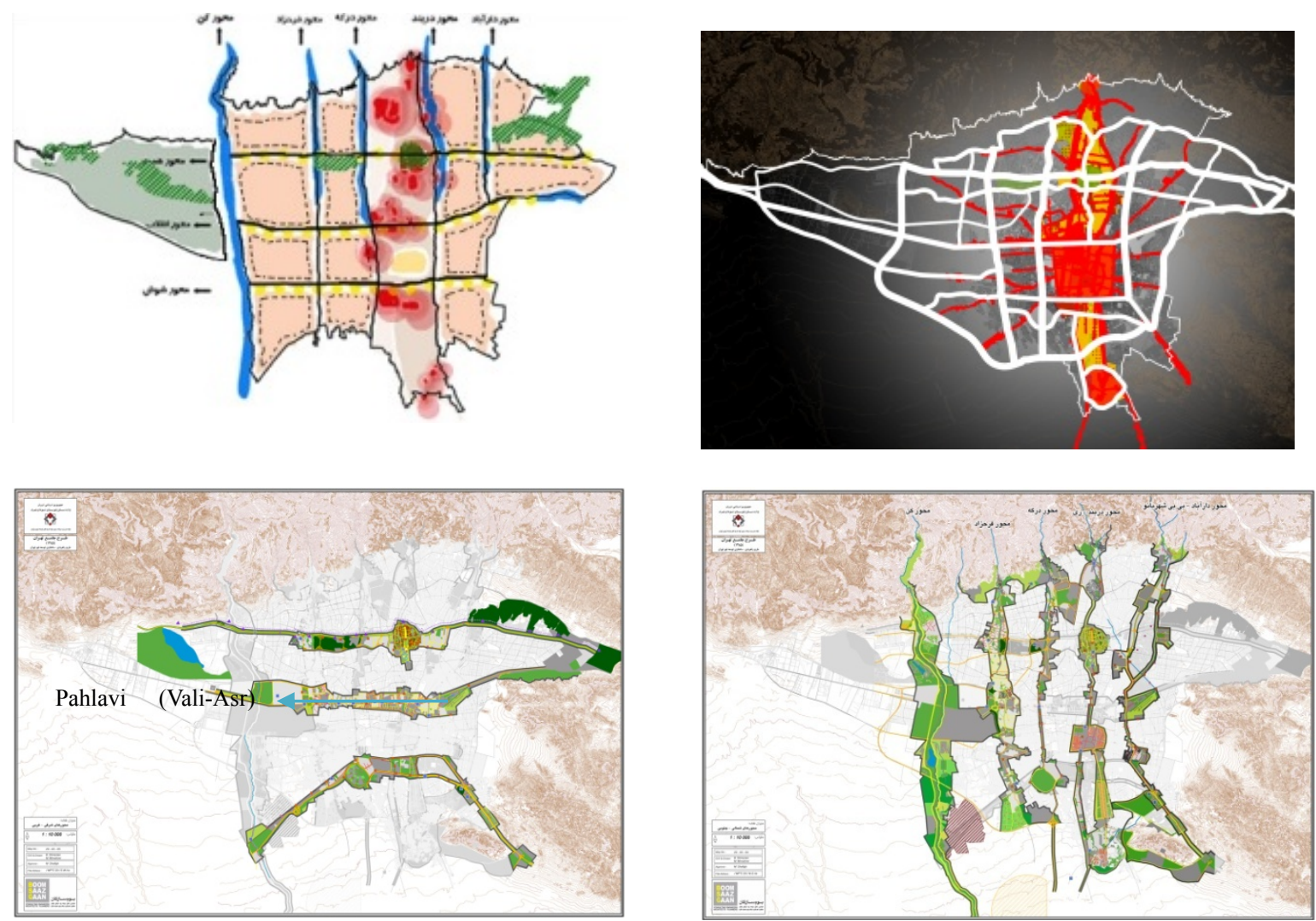

Figure 13. Overall pattern of 2005's master plan

Another weakness in 2005 plan was the absence of strategic vision on the intersection of Vali-Asr Street with historical, cultural importance and especially that is located in the core of Tehran city with Enghelab Street with political, social and economic importance that could have much potential for sociability of urban spaces. In this case not only planners and designers did not pay attention to this opportunity but also Tehran municipality establishes a BRT station and a subway station just in this intersection. It was an obligatory response of urban policies for improvement of mobility with BRT strategy, but it is going to destroy street life in the Vali-Asr Street. The result will clear: air pollution, overcrowded, jammed traffic and auto-dominant conditions (Figure 14). So, there is not sustainable planning and designing thoughts about Vali-Asr locality as an open public space.

Besides, there are detailed projects which aim to improve urban space quality and although among 17 thematic projects two of them are about cultural, social and recreational urban spaces development but still streets locality has been neglected. 


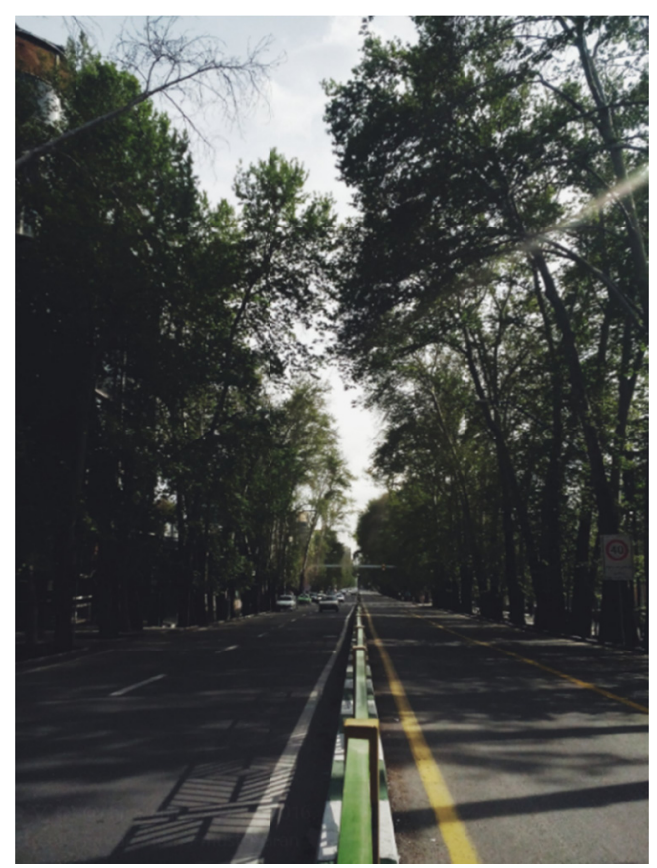

Figure 14.

Appearance of the street in Tehran city had been for three historically main reasons: foremost, streets were for connecting ancient urban elements such as royal casteless, Bazar, military guards, residential areas and their agricultural hinterlands all together that it has defined as the primitive function of street in Iranian cities. Besides, streets had a hidden role that made city more accessible for military activities in the case of turbulence. Second, with expanding city, street had more wide functions simultaneously which connected many parts of the city such as religion, historical, recreational and residential areas and in fact, the street had a structural role. Finally, streets have re-claimed to re-organize their spatial roles with regarding to cultural, historical and natural heritages of the city.

Therefore, the upper ideological approaches with combination of some basic needs of the city, especially in the first and second Pahlavi period, had limited the Vali-Asr Street as an urban space and depreciated its role from a social public space to the space of mobility and the corridor of spatial linkage.

\section{Discussion}

Since embarking modernization thoughts in the first Pahlavi period of Iran, Tehran as a capital of country had been the center of modernization and its appearances in form of buildings, streets and other elements of the city. Vali-Asr streets as a one of the two main streets had crucial roles in the physical growth of the city as predicted in the first master plan. Also, in the second and third master plans, the street had the nodal role in the physical growth of the Tehran city through transporting the huge number of inhabitants and connecting urban cores from south to north of the city. But the fact is socio-economic aspects of the street as a public urban space has been neglected. This lack happened because of various reasons that we summarize them in three categories: First of all is instability of the socio-economic infrastructure of urban development. During the last half century, the economic, political and social structure of Iran has been under the influence of groups of endogenous and exogenous factors, which has meant that evolutions and changes have been affected in a way that is not conducive to stability and equilibrium. The most important is the change from an agricultural based economy to an industrial one and the accompanying rapid progress of urbanization and diminution in the rural lifestyle. In such conditions, and together with the professional and technical limitations imposed on consultants, planning for public urban spaces is restricted by the economic and social structures of the country (Mahdizade, 2005 and Mashadizadeh, 2003).

The second is the ideological approach that took by governments in the past 90 years. In the recent 100 years several social movements took place in urban spaces of Tehran city; the most important orderly are constitutional revolution of 1900 in Qajar period, and the Islamic revolution of 1979 that urban space role was crucial in both of them (Madanipoor, 1998).

After 1979 revolution, modernization process in Vali-Asr Street as an urban space was a spontaneous process that 
happened along the time. In fact, that was not planned as Pahlavi period cause of this belief that this thought brought by Pahlavi's shah from western countries to destroy local culture and made the country like them. The revolution history reveals that how urban space and streets became a scrimmage domain between governments and people for showing their authority (Madanipoor, 1998). Urban spaces have become the place of power representation over time and elites have always tries to expose their powers through the sculptural manifestation in modern urban spaces. This way of representation of power can name 'the ideological war' which has caused to the deficiency on the stability of ideology in management and planning urban spaces.

Therefore, the Vali-Asr Street, could not receive what it deserves cause of instability in socio-economic, even in ideological aspects and planning and design approaches in Iran. The comprehensive urban planning model has been used in Iran for more than fifty years. It was developed in Europe and North America and has been subject to much criticism and subsequently replaced by new more efficient models such as strategic planning. However, in developing world countries generally, and in Iran in particular, it has remained the hegemonic discourse in urban development (Lotfata and Lotfata, 2018). Many of the criticisms leveled at the comprehensive model from the theoretical side consist of the rigidity and stagnancy of its plans, lack of concern for public participation, reliance on model frameworks for its plans, the raising of the land-use map to the status of final document, the idealism and lack of engagement with the real changing world, the attention to masses of detail and lack of concern for the relative ability of the town to actually implement the plan (Panahandeh khah et al, 2009). Therefore, there was not particular attention to the urban space quality and special attention to sociability of streets generally and Vali-Asr street in particular. Here we gathered all opportunities, threats, weaknesses and strengths in the three plan approaches for Vali-Asr Street (Table 1).

Table 1. Socio-spatial characters of Vali-Asr Street in the three master plans

\begin{tabular}{|c|c|c|c|c|}
\hline Plans & Strengths & Opportunities & Weaknesses & Threats \\
\hline 1970 & $\begin{array}{l}\text { - Vali-Asr locality as a first } \\
\text { backbone in Tehran structure } \\
\text { - crossed among historical and } \\
\text { cultural heritages } \\
\text { - linkage between main urban } \\
\text { cores in south(Rey), } \\
\text { center(central Tehran)and } \\
\text { north (Shemiranat) through } \\
\text { this street } \\
\text { - transport huge number of } \\
\text { inhabitants between south, } \\
\text { center and north } \\
\text { - there were variety of social } \\
\text { classes around it } \\
\text { - Vali-Asr street as } \\
\text { socio-political potential for } \\
\text { inhabitants presence specially } \\
\text { in 1979 revolution tar presence for } \\
\text {-Vali-Asr street as } \\
\text { socio-economic potential for } \\
\text { inhabitants preseng } \\
\text { shopping, walking, talking } \\
\text { and recreation activities }\end{array}$ & $\begin{array}{l}\text { - the liner city growth pattern } \\
\text {-government motivations for } \\
\text { modernization } \\
\text { - the longest street in the city with had } \\
\text { connectivity with religion, historic and } \\
\text { cultural cores of old Tehran from south } \\
\text { to north } \\
\text { - }\end{array}$ & $\begin{array}{l}\text {-connected many social } \\
\text { classes with different } \\
\text { socio-economic characters } \\
\text { in conflict with each other } \\
\text {-lack of a socio-spatial } \\
\text { action plans for social } \\
\text { revitalization of street in } \\
\text { modernization process } \\
\text { - Absence of social NGO,s }\end{array}$ & $\begin{array}{l}\text {-unsatisfied social classes } \\
\text {-seeing streets as ideological } \\
\text { exposition } \\
\text { - up-down modernization } \\
\text { thought } \\
\text {-state-led modernization } \\
\text {-instability in socio-economic } \\
\text { infrastructures during white } \\
\text { revolution and transforming } \\
\text { from a traditional society to a } \\
\text { modern society }\end{array}$ \\
\hline 1991 & $\begin{array}{l}\text { - Vali-Asr locality as a first } \\
\text { backbone in Tehran structure } \\
\text { - crossed among historical and } \\
\text { cultural heritages } \\
\text { - was in the after war } \\
\text { developing process in Tehran } \\
\text { as a capital of Islamic } \\
\text { Republic of Iran } \\
\text { - was destination of most daily } \\
\text { trips of citizens to CBD }\end{array}$ & $\begin{array}{l}\text { - the main concept of the city growth } \\
\text { based on } 5 \text { urban cores with centrality } \\
\text { of Vali-Asr street } \\
\text { - to try for reduce north-south conflict } \\
\text { after revolution through improving } \\
\text { transportation infrastructures and spatial } \\
\text { justice in urban services distribution } \\
\text { - beautification movements including } \\
\text { cleaning public spaces } \\
\text {-emergence of popular architecture with } \\
\text { collaboration of chaos in the city } \\
\text { visual(Mirmoghtadaee and Talebi,2006) }\end{array}$ & $\begin{array}{l}\text {-lack of a socio-spatial } \\
\text { action plans for social } \\
\text { revitalization of street in } \\
\text { modernization process } \\
\text {-Absence of social NGO,s }\end{array}$ & $\begin{array}{l}\text {-market-led modernization } \\
\text {-lack of planning and design } \\
\text { strategy for socio-economic } \\
\text { role of the street } \\
\text { - instability in socio-economic } \\
\text { infrastructures during white } \\
\text { revolution and transforming } \\
\text { from a traditional society to a } \\
\text { modern society }\end{array}$ \\
\hline
\end{tabular}




\begin{tabular}{|c|c|c|c|c|}
\hline 2005 & $\begin{array}{l}\text {-linkage with Enghelab street } \\
\text { as a second backbone of the } \\
\text { city in the metropolitan } \\
\text { condition } \\
\text { - crossed among historical and } \\
\text { cultural heritages } \\
\text { - emergence of postmodern } \\
\text { style in architecture in some } \\
\text { parts of the city in the street } \\
\text { path (Ziari and yousefi,2003) } \\
\text { - downtown of the city located } \\
\text { in Vali-Asr and Enghelab } \\
\text { intersection }\end{array}$ & $\begin{array}{l}\text { - strategic approach of master plan in } \\
\text { the case of cultural and historical } \\
\text { heritages in Vali-Asr street path- } \\
\text {-location of many cultural and historical } \\
\text { heritages in Vali-Asr street path as a } \\
\text { strong reason for presence of } \\
\text { inhabitants in urban space }\end{array}$ & $\begin{array}{l}\text { - Absence of social NGO,s } \\
\text { (Rafeeian and Rzavi,2009) }\end{array}$ & $\begin{array}{l}\text {-market-led modernization } \\
\text { - Focus on } 8 \text { main corridors( } 5 \\
\text { north to south and } 3 \text { west to } \\
\text { east )and Vali-Asr street was } \\
\text { only one of them } \\
\text { - pay more attention to } \\
\text { Enghelab street because of } \\
\text { political reasons }\end{array}$ \\
\hline
\end{tabular}

\section{Conclusion}

Tehran open public spaces are shrinking under cultural, political, social and religious conventions and open spaces are vacant lands in hands of central authority. The streets are the corridors of linkage and they are not room to live. The Vali-Asr Street cannot be a place to production of knowledge by inhabitants. Versus to western culture which it has belief on human rationality to control life and production of knowledge, Tehran city as the locality in the middle east involves religious beliefs on shaping inhabitants-built environment. In some circumstances, this kind of perspective on built environment causes to ignore inhabitants' real tendencies. Modernization and making progress for Islamic countries are defining in considering local dynamics (Lotfata, 2013).

Urban space is a combination of social relationships in a city that is in a semantic context that meets the needs of a city's citizens. This environment is a place for the flow of social life and the basis of the social interaction of citizens of a city. But what is currently visible in cities is no longer like the real meaning of urban space. And gradually, the semantic and social dimension of it diminished. Urban design needs to move away from the superficial aesthetics and visual forms aspects of cities (Lynch, 1981; Jacobs, 1961; Lotfata and Lotfata, 2018). A multi-disciplinary problem-solving operation, often involving architect, planners, social engineers, policy makers, civil engineers, and psychologists (Lotfata and Sadeghi, 2009) should be considered in the planning process.

\section{References}

Ambinakudige, S., Parisa, D., Cappello, G. C., \& Lotfata, A. (2017). Diversity or Segregation? A Multi-decadal Spatial Analysis of Demographics of Atlanta Neighborhoods. Spatial Demography, 5, 123. https://doi.org/10.1007/s40980-017-0034-z

Azad Aramaleki, T. (2001). Modenrization Notion in Iran. Tehran University Publication.

Grigor, T. (2009). Building Iran: Modernism, Architecture, and National Heritage under the Pahlavi Monarchs. New York: Periscope.

Habibi, S. M. (1996). From Shar to City. Tehran University Publications.

Hamidi M. (1997). The Transformation of The Urban Structure in The First Pahlavi Era, The Urban Structure of Tehran. Technical Consulting Organization in Tehran, No. 2.

Jacobs, J. (1961). The Death and Life of Great American Cities. New York, Random House.

Lenczowski, G. (1978). Iran under the Pahlavi's. Hoover university press Stanford California.

Lotfata, A. (2008). Effect of Environmental Factors on Behaviors and Learning, in Educational Spaces (Especially Elementary Schools), Modiriyat Shahri, No.21.

Lotfata, A. (2012). Socio-Spatial Resilience Strategic Planning Through Understanding Strategic Perspectives on Tehran and Bath. World Academy of Science, Engineering and Technology, 6(11).

Lotfata, A. (2013). Epistemological Differences in Tactical and Strategic Spatial Planning. Global Journal of Computer Science and Technology Neural \& Artificial Intelligence, 13(1).

Lotfata, A. (2013). Transformation of Urban Spaces through Time-Space Politics towards Ethical Developing Urban Spaces in Turkey Context. Global Journal of Human Social Science Political Science, 13(4).

Lotfata, A. (2015). Urban Diversity in the Middle East: A Case Study of Tehran. International Journal of Culture and History, 2(1). https://doi.org/10.5296/ijch.v2i1.7887

Lotfata, A. (2018). Urban Mind. International Journal of Culture and History, 5(2). 
https://doi.org/10.5296/ijch.v5i2.13530

Lotfata, A., \& Sadeghi, M. J. (2009). The Creative City, Reflecting New Planning Tendencies for Cities, $5^{\text {th }}$ Symposium on Advances in Science and Technology, Mashhad, Iran.

Lotfata, Y., \& Lotfata, A. (2018). Effect of Physical Changes on the Spatial Structure of Historical Area, the Historical District of Urmia City as a Case Study. Journal of Sustainable Development, 11(4). https://doi.org/10.5539/jsd.v11n4p174

Lotfata, Y., \& Lotfata, A. (2018). Resiliency of Open Public Space (Streets) through Transferring Memory "Graffiti and Wall Arts in the Tehran Streets. International Journal of History and Scientific Studies, 1(3).

Lotfata, Y., \& Lotfata, A. (2018), Street as Common Space. International Journal of Culture and History, 5(2). https://doi.org/10.5296/ijch.v5i2.13473

Lynch, K. (1981). Good City Form. Cambridge, MA, MIT Press.

Madanipour, A. (1998). Tehran making of a metropolis, World cities series books, Chichester University.

Mahdizade, J. (2005). Strategic Urban Development Planning: Recent world experience and its position in Iran, Tehran (Persian).

Mashadizadeh, N. (2003). An Analysis Urban Planning Characteristics in Iran. Elm and Sanaat University Press, Tehran (Persian).

Ministry of Housing and Urban Development. (2006a). Tehran master plan of 1970.

Ministry of Housing and Urban Development. (2006b). Tehran re-ordering plan of 1991.

Ministry of Housing and Urban Development. (2006c). Structural-strategic plan of Tehran 2005.

Mirmoghtadaee, M., Talebi, J., \& Bahreini, H. (2006). Urban physical identity, case study of Tehran. Center for housing and building research (Persian).

Murdoch, J. (2006). Post-structuralist Geography. Sage Publications.

Panahandeh khah, M., Farhoodi, R., Gharakhlu, M., \& Ghadami, M. (2009). A Critique of the Prevailing Comprehensive Urban Planning Paradigm in Iran: The Need for Strategic Planning. International Journal of Planning Theory.

Pilehvar, A. A. (2007). Partnership a New Approach for the Urban Management of Iran, Case Study-Management of Mashhad Religious Metropolis. International Journal of Sustainable Development and Planning, 2(4). https://doi.org/10.2495/SDP-V2-N4-435-444

Rafeeian, M., \& Razavi, H. (2009). Urban environment quality improvement using design-based planning approach. Journal of Modarres University.

Rahnamaee, M. T., \& Shahhosseini, P. (2005). Urban planning process in Iran. Samt Publications.

Ziari, K., \& Yousefi, A. (2003). Tehran physical growth in process of modernism, post modernism and globalization. Journal of Modarres University.

\section{Copyrights}

Copyright for this article is retained by the author(s), with first publication rights granted to the journal.

This is an open-access article distributed under the terms and conditions of the Creative Commons Attribution license (http://creativecommons.org/licenses/by/4.0/). 